\title{
PERANCANGAN SISTEM APLIKASI PENGGAJIAN PEGAWAI DALAM RANGKA EFISIENSI REFORMASI BIROKRASI: STUDI KASUS DI KEMENTERIAN PERDAGANGAN RI
}

\author{
Agung Seska Nori \\ Informatika/Fakultas Teknik dan IImu Komputer \\ Universitas Indraprasta PGRI \\ Jakarta, Indonesia \\ e-mail : agunxseska@yahoo.com
}

\begin{abstract}
ABSTRAK : Teknologi dibuat untuk membantu mempermudah aktivitas manusia, termasuk aktivitas di perkantoran. Berkembangnya teknologi di bidang informasi sejalan dengan berkembangnya teknologi komputer sebagai alat pendukung. Komputer memiliki tingkat kecepatan akurasi yang tinggi dalam pemrosesan data. Melalui teknologi komputer kita dapat melakukan pengolahan data yang meliputi penyimpanan, perhitungan, perbandingan, masukan dan keluaran data sebagai informasi yang dibutuhkan dalam waktu yang cepat, tepat, dan akurat. Pada penelitian ini, dirancang suatu sistem aplikasi penggajian pegawai di lingkungan Kementerian Perdagangan Republik Indonesia. Tujuannya adalah untuk mempermudah proses penggajian dan mengorganisir proses pelaporan penggajian. Metode penelitian yang digunakan adalah grounded research. Software yang digunakan dalam penelitian yaitu Java (Netbeans IDE versi 8.0), MySQL 5.5.32, dan XAMPP 3.2.1. Metode pengembangan sistem yang digunakan oleh peneliti untuk membuat sistem informasi penggajian adalah metode waterfall. Hasil dari penelitian yaitu telah dibuat suatu sistem aplikasi penggajian dengan luaran berupa laporan pegawai, laporan absensi, laporan detail gaji, laporan penggajian, dan laporan slip gaji.

Kata Kunci : Teknologi Komputer, Sistem penggajian pegawai, Kementerian Perdagangan
\end{abstract}

ABSTRACT : Technology is created for helping human's activity to become easier, including for activities in an office. The growth of the information technology has followed by growth of the computer technology as its proponent. Computer has high grade accuracy in processing data. By an information technology, human can process data become faster and easier. In this research, an employee payroll application system was created the Ministry of Trade of the Republic of Indonesia. The aim was to simplify the payroll process and organize payroll reporting process. The method that was used in this research is grounded research. Software used in this research are Java (Netbeans IDE version 8.0), MySQL 5.5.32, and XAMPP 3.2.1. The system development method to create a payroll information system was the waterfall method. The results of the study is a payroll application system with output in the form of employee reports, attendance reports, detailed salary reports, payroll reports, and pay slip reports.

Key Words : Computer Technology, Employee payroll system, Ministry of Trade

\section{Pendahuluan}

Peranan teknologi informasi di perkantoran saat ini hampir tidak dapat dipisahkan dari setiap aktivitas di perkantoran tersebut. Teknologi informasi merupakan gabungan antara teknologi telekomunikasi dan komputerisasi. Teknologi informasi ini telah merambah pada segala bidang, termasuk bidang penggajian dalam sebuah perusahaan dan perkantoran.
Melalui proses komputerisasi, seluruh kegiatan mulai dari menginput data, memproses data, menyimpan data, dan mendistribusikan data terkait penggajian dapat berjalan secara otomatis, sehingga tidak lagi dilakukan secara manual.

$$
\text { Bagian keuangan pada Bidang }
$$

SDM Kementerian Perdagangan memiliki peranan yang sangat penting 
dalam memberikan informasi tentang penggajian. Sistem dan prosedur pada bagian keuangan terbilang sangat kompleks, termasuk sistem akuntansi penggajian yang fungsinya terkait erat dengan para karyawan[1]. Permasalahan gaji merupakan permasalahan yang sensitif. Besarnya gaji dapat mempengaruhi kualitas, kuantitas, dan motivasi kinerja karyawan. Ukuran gaji bagi karyawan dianggap mencerminkan nilai pekerjaan karyawan tersebut di antara diri mereka sendiri, keluarga dan komunitas[1].

Akan tetapi, masih terdapat kendala dalam perhitungan dan pemrosesan data gaji kepegawaian. Salah satunya adalah belum terintegrasinya antara data kepegawaian dengan data gaji, sehingga proses perhitungan data gaji pegawai masih dilakukan secara manual. Perhitungan gaji tersebut dilakukan dengan merinci satu persatu pegawai berdasarkan besarnya tunjangan dan pemotongan gaji sesuai aturan Kementrian Perdagangan RI. Hal ini tentu saja membutuhkan waktu yang lama serta memiliki resiko human error yang cukup tinggi. Oleh karena itu, untuk mempermudah pengelolaan data kepegawaian untuk penggajian, dibutuhkan suatu sistem informasi penggajian pegawai yang cepat, tepat, dan akurat.

Beberapa poin penting permasalahan yang sedang terjadi saat penelitian adalah sebagai berikut:

a. Penulisan data pegawai masih dilakukan secara manual,

b. Proses pencatatan secara manual memerlukan tempat penyimpanan yang sangat luas, akibat kertas yang bertumpuk serta memerlukan waktu yang lama dalam proses pencarian data kembali,

c. Penggajian menjadi tidak efisien dan memungkinkan terjadi kesalahan akibat waktu yang lama dalam pencarian data dan human error,
Pembuatan laporan yang
dilakukan secara manual yang memungkinkan terjadinya kesalahan. Ini memerlukan waktu yang lama dalam mengubahnya.

Sistem informasi penggajian dirancang untuk menangani transaksi dan perhitungan gaji karyawan dengan memastikan validitas, kelengkapan otorisasi, klasifikasi penilaian, ketepatan waktu dan akurasi serta ikhtisar masing-masing transaksi penggajian dan upah[2]. Tujuan dibuat sistem informasi penggajian pada Kementerian Perdagangan $\mathrm{RI}$ ini adalah agar dapat mendukung integritas data, kemudahan pengaksesan, dan kemudahan pengelolaan data pegawai sehingga dapat mendukung kelancaran pelaksanaan dan fungsi bidang SDM. Sistem ini juga memfasilitasi perekaman, mengolah dan menangani database kepegawaian dan proses penggajian pegawai secara otomatis sehingga dapat memberikan informasi dalam bentuk laporan daftar dan rekapitulasi yang dibutuhkan oleh pihak manajerial secara cepat, akurat dan selalu mutakhir mengenai kondisi penggajian kepegawaian [3], [4].

\section{Metode Penelitian}

Metode penelitian yang digunakan adalah metode Grounded Research. Metode Grounded Research merupakan metode penelitian yang berdasarkan fakta dan melakukan analisis perbandingan untuk mengadakan generalisasi empiris, menerapkan konsep-konsep, membuktikan teori, dan mengembangkan teori [5]. Pada metode ini, proses pengumpulan data dan analisis data berjalan pada waktu yang bersamaan. Langkah-langkah Grounded Research yang diterapkan dalam penelitian ini adalah :

a. penentuan masalah yang ingin diselidiki.

$\mathrm{Di}$ lapangan, permasalahan yang ditemukan adalah adanya 
kesulitan dalam menghitung jumlah gaji yang akan dibayarkan pada para karyawan per bulannya. Jumlah gaji ini dihitung berdasarkan jumlah hari kerja, tunjangan, lembur, dan sebagainya.

b. pengumpulan data yang dibutuhkan.

Data yang dimaksud berupa database kepegawaian.

c. analisis dan penjelasan.

Setelah data dikumpulkan dan aplikasi dibuat, aplikasi diuji coba dan dianalisis kebergunaannya.

d. pembuatan laporan.

Setelah aplikasi diselesaikan, langkah selanjutnya adalah pembuatan laporan. Hal ini diperlukan salah satunya untuk mendokumentasikan hasil penelitian.

Pengembangan sistem yang digunakan untuk membuat sistem informasi penggajian adalah metode waterfall. Metode Waterfall adalah proses pengembangan perangkat lunak berurutan, yang memandang kemajuan sebagai sesuatu yang terus mengalir ke bawah (seperti air terjun) melewati fase perencanaan, implementasi (konstruksi), dan pengujian [6]. Metode ini ditunjukkan seperti gambar di bawah ini:

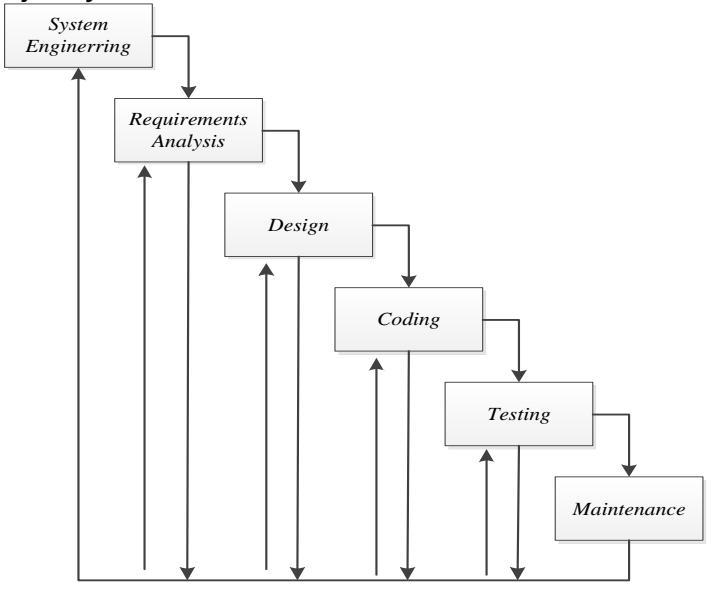

Gambar 1. Metode Waterfall [7]

Berikut ini adalah penjelasan dari tahapan-tahapan yang terdapat dalam metode Waterfall :

1. System engineering (rekayasa perangkat lunak),

Pada tahap ini dilakukan pengumpulan database kepegawaian dan penetapan kebutuhan semua elemen sistem.

2. Requirements analysis,

Pada tahap ini dilakukan analisis terhadap permasalahan yang dihadapi dan menetapkan kebutuhan perangkat lunak, fungsi performance dan interfacing. Permasalahan yang dimaksud adalah sulitnya menghitung jumlah yang akan dibayarkan per bulannya.

3. Design,

Pada tahap ini ditetapkan domain informasi untuk perangkat lunak, fungsi dan interfacing serta merancang tampilan aplikasi .yang akan dibuat.

4. Coding (implementasi),

Pada tahap ini dirancang pengkodean yang mengimplementasikan hasil desain ke dalam kode atau bahasa yang dimengerti oleh mesin komputer dengan menggunakan bahasa pemprograman tertentu. Bahasa pemrograman yang digunakan 
adalah Java (Netbeans IDE versi 8.0, MySQL 5.5.32, dan XAMPP 3.2.1).

5. Testing (pengujian),

Pada tahap ini dilakukan kegiatan untuk melakukan pengetesan program yang sudah dibuat apakah sudah benar atau belum diuji dengan cara manual. Jika hasil pengetesan sudah benar, maka program boleh digunakan.

6. Maintenance (perawatan), Pada tahap ini dilakukan perawatan terhadap aplikasi secara berkala.

\section{Hasil dan Pembahasan}

Sistem penggajian terus mengalami perubahan seiring dengan perubahan ekonomi, peraturan pemerintah, dan kebutuhan karyawan yang terus meningkat [8]. Oleh sebab itu, agar bagian keuangan tidak terus membuat perubahan dan perhitungan manual, dirancanglah suatu sistem yang dapat memudahkan pengolahan data penggajian pegawai. Di dalam sistem ini, terdapat prosedur penggajian yang mencakup faktor faktor dalam perhitungan gaji. Berdasarkan analisis sistem yang sedang berjalan, terdapat kelemahankelemahan dan pokok permasalahan yang terdapat pada sistem penggajian pegawai, sehingga terdapat beberapa alternatif permasalahan yang dapat dicoba, yaitu :

a. Agar tidak terjadi keterlambatan dalam proses pengerjaan dan informasi, sebaiknya dikoordinasikan dengan baik dan terkomputerisasi dengan benar antara sub sistem yang satu dengan yang lainnya, Kementerian Perdagangan sebaiknya membuat rancangan sistem yang dapat meringankan dalam mengerjakan, mengumpulkan dan mengecek data khususnya pada pengolahan absen Pegawai dan pembuatan laporan. b. File ataupun data yang sudah dikerjakan sebaiknya disimpan ke harddisk atau alat penyimpanan data lain, dan jika perlu dibuat backup-nya jika saat terjadi kesalahan kita masih memiliki cadangan file ataupun datanya.

c. Sebaiknya komputer yang digunakan untuk memproses data diupgrade, sehingga pemrosesan data tersebut dapat dilakukan lebih baik, cepat (menghemat waktu) dan tepat. Dengan dibuatnya sistem Penggajian Pegawai dengan sistem terkomputerisasi ini, diharapkan dapat mempermudah proses pengerjaan dan pengecekan data khususnya pada proses pembuatan laporan dan pengolahan penggajian pegawai.

Sistem yang baru diusulkan merupakan komputerisasi bagi sistem lama atau sistem berjalan, dimana cara kerja atau prosedur sistem yang baru tidak jauh berbeda. Dengan pengalihan ini akan meningkatkan ketelitian, ketepatan dan pengefisienan waktu. Penggunaan sistem informasi perhitungan penggajian dapat mengakibatkan pengambilan keputusan manajerial yang lebih baik, efektif dalam proses transaksi dan pengendalian internal, meningkatkan kualitas laporan, dan meningkatkan kinerja pegawai [9]. Prosedur sistem penggajian pegawai yang dilaksanakan dijelaskan pada beberapa proses sebagai berikut:

1. Proses Pendataan Pegawai.

Pendataan pegawai akan dilakukan ketika ingin mengevaluasi kinerja Pegawai. Hasil kinerja Pegawai yang dilihat dari data absensi pegawai akan dijadikan pendataan ketika sudah waktunya untuk pengimputan gaji, berkas dan data pegawai akan diinput oleh Admin dan akan diberikan ke bagian keuangan untuk dilihat berapa jumlah banyak presensi yang nantinya akan diputuskan berapa jumlah gaji yang akan diterima oleh pegawai. 
2. Proses Absensi Pegawai.

3. Proses Penggajian Pegawai.

4. Proses pembuatan laporan.

Setelah selesai melakukan Penggajian Pegawai, maka bagian keuangan akan membuat laporan bulanan untuk dilaporkan kepada pimpinan yang dapat dicetak di kertas atau dapat dilihat pada layar komputer. Proses tersebut dapat dilakukan dengan program aplikasi yang telah dibuat.

Pada sistem informasi Penggajian Pegawai pada Kementerian Perdagangan $\mathrm{RI}$ digambarkan melalui Diagram Alir Data (DAD) sebagai berikut :

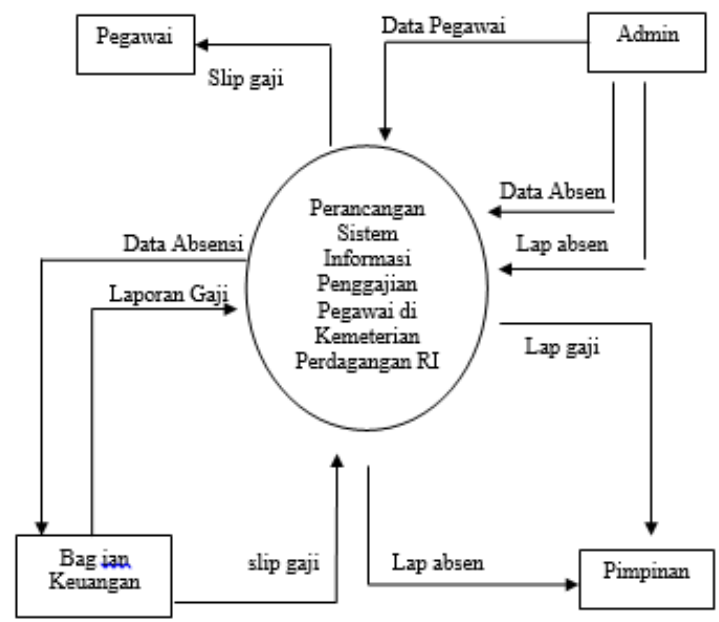

Gambar 2. Diagram Konteks Sistem Berjalan Sumber: dokumen pribadi

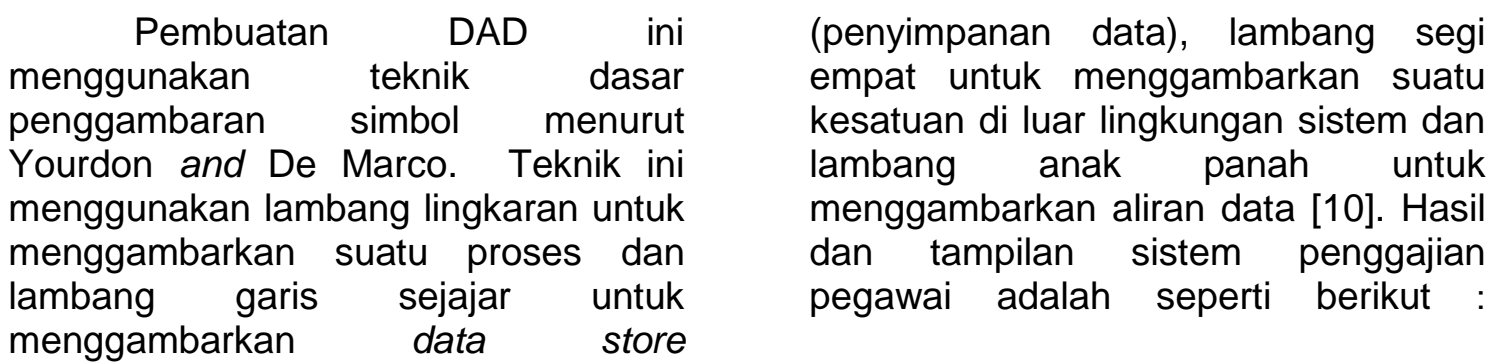

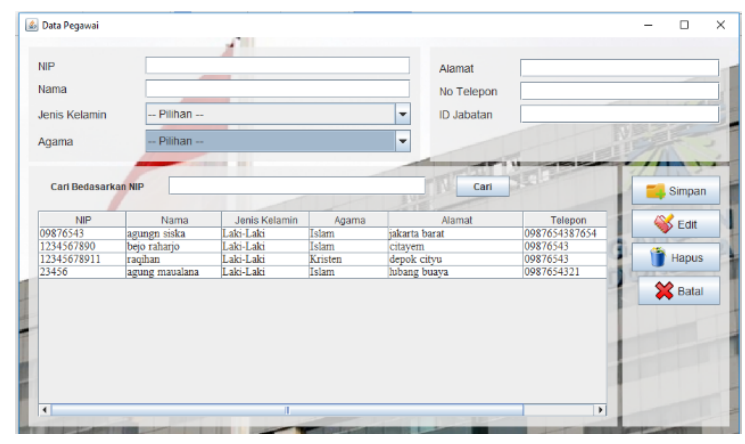

Gambar 3. Form Data Pegawai

Sumber : Dokumen pribadi

Gambar 3 merupakan tombol yang terdiri dari tombol Tambah rancangan tampilan form Data untuk memasukkan data pegawai baru, Pegawai. Form ini memiliki beberapa tombol "Simpan" untuk menyimpan 
data Pegawai, tombol Ubah untuk mengubah data yang telah tersimpan, tombol Batal untuk membatalkan semua data yang telah disimpan, serta tombol Hapus untuk menghapus data yang telah disimpan.

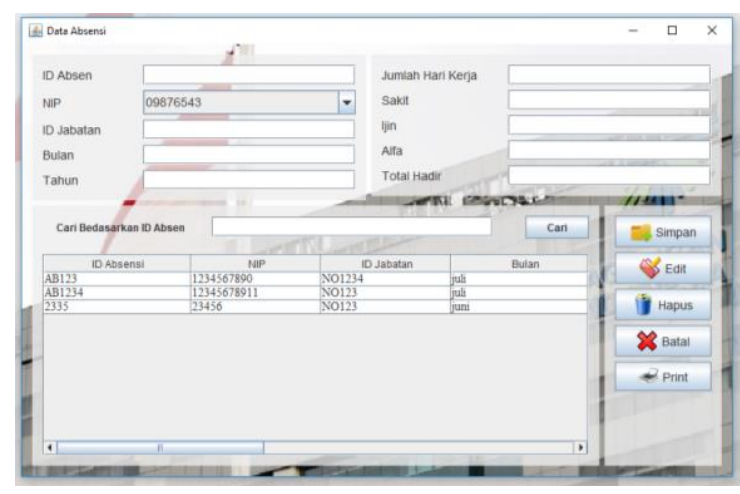

Gambar 4. Form absen

Sumber : Dokumen pribadi

Data absensi ini memiliki beberapa tombol yang dapat digunakan untuk menambah, menyimpan, mengubah, membatalkan, dan menghapus semua file data absen yang telah disimpan. Data ini juga memiliki tombol yang juga digunakan keluar dan kembali ke tampilan menu utama.

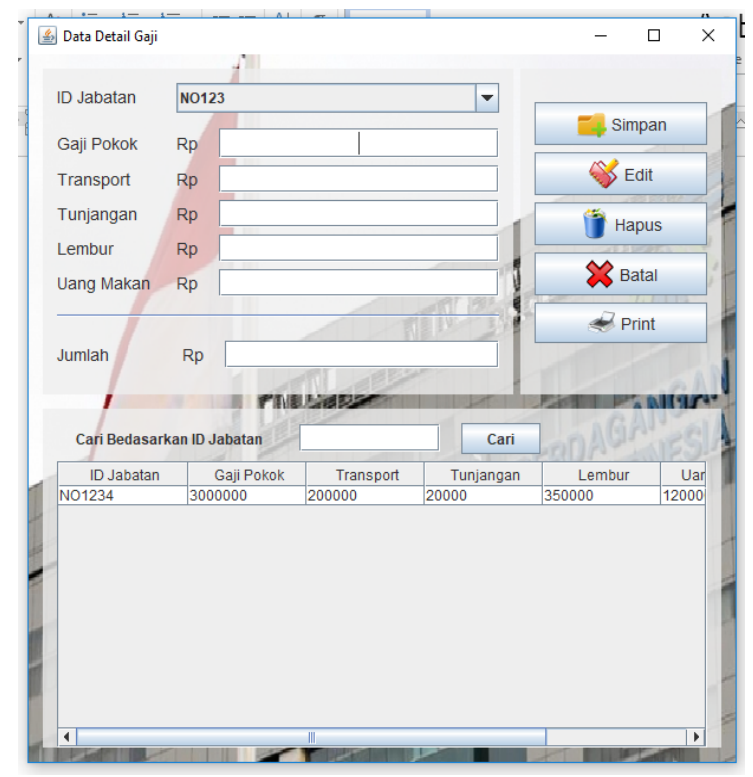

Gambar 5. Form data detail gaji

Sumber : Dokumen pribadi

Gambar 5 merupakan rancangan tampilan form Data Detail Gaji Pegawai yang digunakan untuk menginput data detail gaji. Pada data ini terdapat beberapa tombol yang berfungsi untuk menambahkan data baru, menyimpan atau membatalkan semua kegiatan yang telah dilakukan, dan mengeluarkan dari form Data Detail Gaji untuk kembali ke menu utama. 


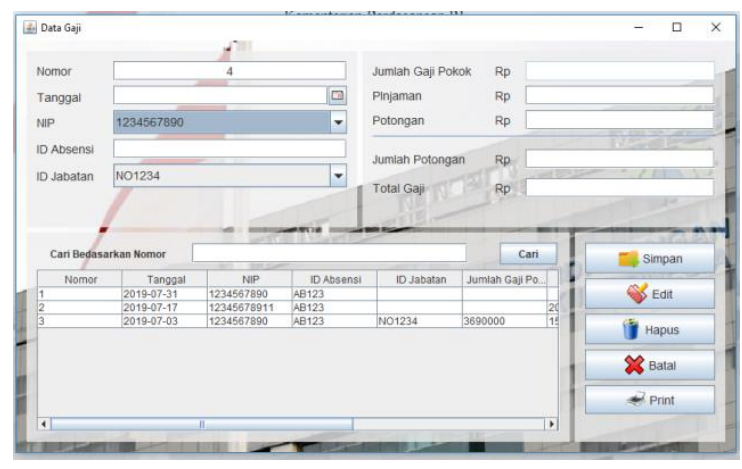

Gambar 6. Form Penggajian

Sumber : Dokumen pribadi

\begin{abstract}
Form Penggajian Pegawai berfungsi untuk menyimpan data penggajian pegawai. Pada menu ini, juga terdapat tombol yang berfungsi untuk penambahan data penggajian pegawai, penyimpanan data penggajian pegawai, pengubahan hasil penyimpanan data penggajian pegawai, pembatalan semua tindakan yang dilakukan pada form ini, dan keluar dari tampilan form data penggajian pegawai.
\end{abstract}

\section{Kesimpulan}

Dengan dibuatnya aplikasi sistem penggajian pegawai, semua kegiatan yang berhubungan dengan pengolahan data sistem Penggajian Pegawai dapat berjalan dengan lebih mudah dan cepat. Pada aplikasi ini, bagian administrasi dapat menangani pekerjaan penginputan data sistem Penggajian Pegawai dengan cepat dan akurat serta dapat diperbarui dengan mudah. Melalui aplikasi ini pekerjaan yang memerlukan kecepatan dan ketepatan informasi dapat dilakukan dengan lebih mudah dan cepat.

Dengan diterapkannya sistem Penggajian Pegawai merupakan salah satu langkah maju dalam penerapan teknologi informasi. Sistem Penggajian Pegawai ini hanya sebagai penunjang proses sistem penggajian pegawai untuk mengefisienkan waktu dan keamanan data yang setidaknya dapat membantu bagian administrasi di dalam sistem Penggajian Pegawai

\section{Daftar Pustaka}

[1] F. Alfiandi, "The Implementation of Payroll Accounting System as an Effort to Improve the System of Internal Control ( A Study at PDAM Kota Malang )," JAB (Jurnal Adm. Bisnis), vol. 14, no. 1, pp. 1-10, 2014.

[2] Mulyadi, Sistem Akuntansi, V. Jakarta: Salemba Empat, 2013.

[3] A. Sani and I. Karmawan, Perancangan Sistem Informasi Penggajian. Jakarta: PT. Graha Indotek Security, 2011.

[4] I. Wignyowiyoto and S. Rofiah, "Sistem Informasi Penggajian Karyawan Berbasis Desktop," Bina Insa. Ict J., vol. 4, no. 2, pp. 179188, 2017.

[5] M. Nazir, Metode Penelitian. Bogor: Ghalia Indonesia, 2013.

[6] C. Tristianto, "Penggunaan Metode Waterfall untuk Pengembangan Sistem Monitoring dan Evaluasi," Teknol. Inf. ESIT, vol. XII, no. 01, pp. 8-22, 2018.

[7] Jogiyanto, Analisis dan Desain Sistem Informasi. Yogyakarta: Graha IImu, 2010.

[8] S. Nilasari, Panduan Praktis Menyusun Sistem Penggajian dan Benefit, I. Jakarta: Raih Asa Sukses, 2016.

[9] Suryanto, "Design and Analysis : Payroll of Accounting Information 
System," CommlT, vol. 5, no. 1, pp. 24-26, 2011.

[10] R. Afyenni, "Perancangan Data Flow Diagram Untuk Sistem
Informasi Sekolah (Studi Kasus

Pada SMA Pembangunan

Laboratorium UNP)," Teknoif, vol. 2, no. 1, pp. 35-39, 2014. 